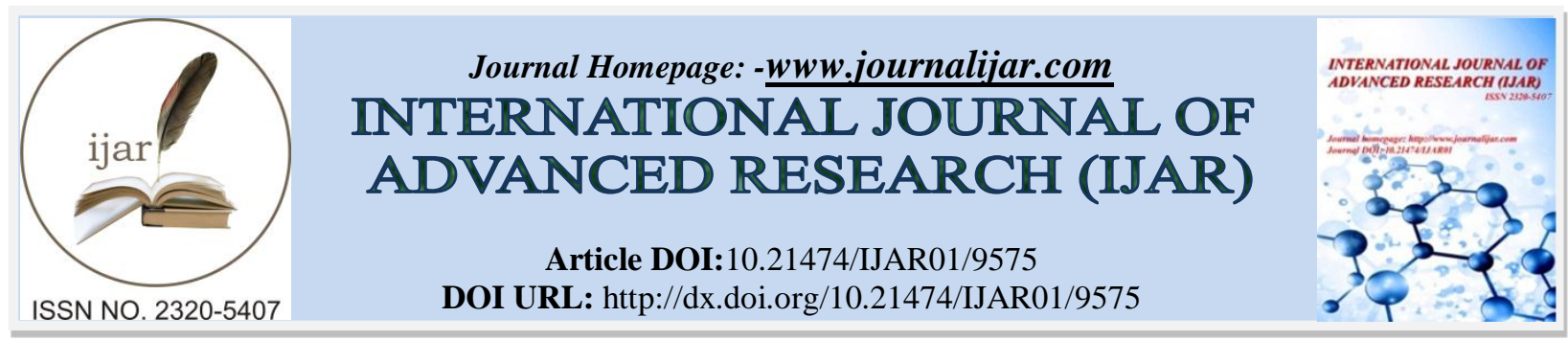

RESEARCH ARTICLE

\title{
RHETORICAL ANALYSIS OF THE REPRESENTATIONS OF FEMALE CHARACTERS IN PRADIP NEPAL'SSWAPNIL SAHAR.
}

Sushil Rajbhandari.

Pokhara University, Department of English.

\section{Manuscript Info}

Manuscript History

Received: 14 June 2019

Final Accepted: 16 July 2019

Published: August 2019

Key words:-

rhetorical, women, characters, patriarchal, portrayal.

\section{Abstract}

Pradip Nepal, in addition to being a popular novelist, is a renowned political figure of Nepal. His political ideology is well reflected on the plots of his novels, and his characters seem strongly influenced by the socialist doctrine. Nepal seems toposit female characters asmale equals tacitly or overtly, and at some point even shows female characters surpassing their male counterparts. This paper analyzes female characters who preform varied roles alongside their male counterparts and strive to show how females too can walk with men neck and neck. These female characters undergo perceptible transformation with the passage of time and changing contexts and defy the patriarchal conventions. That said, however, it would be no overstatement to state that Nepal's portrayal of women characters is often governed by his own positionality as a male writer. Despite presenting women as strong managers and decision makers, often he places them as sidekicks who end up supporting the other male characters or rendered less significant to the other prominent male characters in the novel. However, it would be unfair to say Nepal presents women as frail characters since it is the female characters that have heavily contributed to the success of the male characters.

Copy Right, IJAR, 2019,. All rights reserved.

\section{Introduction:-}

Pradip Nepal, in addition to being aninfluential Nepalese political leader with a considerably long struggle story against the one party Panchayat system to his credit, is a renowned litterateur. Nepal's novel, Swapnil Sahar, is suffused with political ingredients thatfirmly rest against a politically motivated plot. His characters, in line with the progression of the storyline, are molded by unfolding political developments. This paper, however, will be invested in examining the portrayal of women characters in the novel against the backdrop of their political orientations. Nepal's novel was published only about one and a half decade ago. However, the storylinesprawls in the one party systemPanchayat era in Nepal that spanned thirty years, likening it to a retrospective journey of the writer, colored with his very own political tilt. The weight of the plot is heavily shouldered by male characters but they have been affected by worthy female characters who at a glanceseem to carry little significance.

Even if these characters raise their voice, it is the grammar of patriarchy they use as patriarchy exerts influences over probable dissenting voices to make these conform to its norms. This situation is in a way analogous to that of Emily Dickinson's, a famous poet, who despite being well versed in poetry was "forced to be interested in margins and silences of patriarchy and has to speak in a kind of code, because of the oppressiveness of patriarchy" (Jacobs, 
p.243). Nepal's characters, however, are not helpless to the extent that they share the plight of same intensity with Dickinson. They, using some rhetorical tools, succeed in making themselves visible.These characters, however, are not so heavily marginalized, and in fact seem to outperform their male members in a number of hostile situations.

Ananta, the lead character in Swapnil Sahar, initially "feels happy whenever he sees girls from the Padmakanya College and he really doesn't know why...." (Nepal, p. 4). Ananta indeed enjoys the sight of girls from any other college equally but does detest boys who sit around and tease them. This, it can be argued, is a very natural phenomenon for every young person regardless of the ascribed sex harbors attraction towards the opposite sex. Although initially one may sense whether women are portrayed as object of desire, Ananta's disdain towards those who tease girls shows otherwise. Similarly, as the story travels to and fro in the past and the present, the writer speaks of Ananta's mother in a positive light. Although Ananta's father is mentioned, he exists only as a silhouette. It is the mother that is actively seen in the novel, and establishes her prominence. For example, it is the mother who with much pain parts with her son as"had it not been for the sake of his studies Mother did not want to send her son to Nepal valley so far off...." (Nepal,p. 4). Mother loves Ananta immensely but she does not permit this love of hers to tamper with the progress of her son; she rather chooses to swallow the bitter pill of parting. This is one of the earliest examples in the novel that illustrates the position that has been delegated to woman in the novel.

In place of presenting an emotionally frail woman, the novelist creates a mother character who is more concerned about the bright future of her son even if that means a long spell of separation with him. In this vein, it can be inferred that the novelist deliberately chooses mother over father with a view to exhibiting women awareness and receptivity towards education. The next lady character introduced along the journey is BishnumayaMajhi. BishnumayMajhiis presented as a rather mystic and influential character who according to Kaka owns a shop in Tribeni and "it was really because of BishnumayaMajhi that a path been made in the sloppiest terrain. The path is difficult but it is rather straight..." (Swapnil Sahar,p. 9).The writer does not elaborate much on this character but apparently it can be understood that she must have made a significant contribution to ease the journey of the travelers thereby constructing a foot trail in most adverse landscape.

Given that the novel is set in the Panchayat era Nepal, and the location of the novel at the start is an outlying area, it is interesting yet bizarre to note that a lady who probably was not so much educated and was not a representative of a well off class as she ran "a teashop in Tribeni" (Swapnil Sahar, p. 9) had been charitable enough to help make a foot trail. The novelist clearly intends to show that regardless of their economic standing and educational qualifications, women are aware of their social obligations and are capable of taking the lead role in initiating social service, surpassing their male counterparts. The character of BisnuMajhi provides some hints to the reader that the novelist is trying to promote a communist doctrine that seems to strongly advocate for women rights and empowerment.

With the advance in the journey, Ananta recalls a time in his boyhood when while crossing a locally constructed wooden bridge he felt terribly scared as the bridge began to rock from side to side. Terrified he screamed and his mother who was behind him yelled "my son" (Nepal, p. 9) and in no time "he was tightly grabbed by a pair of hands" (p. 9). This speaks of concern which females show over their loved ones as his mother then "carried him on her back and said, 'Don't worry. I am here. You as a boy shouldn't be scared!” (Swapnil Sahar, p. 9). Imperceptibly, perhaps, the novelist seems to be attempting to establish male chauvinism here by unnecessarily providing extra prominence to a male entity. But in so doing, the mother might have lowered the position of women and given some support to the proponents of male chauvinism. Suresh Lohani (2019) in "Constructing nontraditional Rhetoric: Critical Study on Gloria Anzaldua and Suresh Canagarajah"states that "Often leading voices from within the communities seem to tune well to the interests of the dominant cultures and in so doing diverse voices are strategically muted" (p.118). However, this can also be taken as a mere utterance of an overtly caring mother who had already internalized the gender biases prevalent in the society. Another female character the novelist mentions is Ananta's sister. There seems to be quite a big age gap between Ananta and his sister and it is apparent that she stands next to mother in Ananta's life as "Ananta who had already passed the S.L.C exam had 'grown ten years younger' on seeing his sister and coyly smiled a little revealing a few teeth" (Swapnil Sahar, p. 13).This is nothing significant as such in the course of the journey but obliquely it does show that female figures in a family have always taken it as their responsibility to take care of the other male members and this happens not out of any obligation but as a result of inherent character traits which seem to associate with their nursing instincts. 
The next female character that has been portrayed as assertive, outspoken, and daring is Anita.She later becomes Ananta's life partner. It is with Anita that Ananta's infatuation story begins and this eventually blossoms into genuine love full of commitments and promises. However, unlike most of the other love stories, it is Anita here who takes the initiation in expressing her love to Ananta. Ananta in his early school days is strongly challenged by Anita in studies and an open rivalry existed between the two. There was a throat cut competition between the two for "in the first quarterly exams Anita defeated Ananta" (p. 15) and "in the final exams he defeated her by a narrow margin of five marks" (p. 15). However, things began to change gradually as they moved to senior classes and that began to nurse mutual attraction between the two. It seems to start with Anita but soon enough Ananta too was induced into attachment though he kept it a low profile affair. Anita would frequent Ananta's home and complain to Ananta's mother in a subtly flirtatious manner that "he treated her like a stranger" (Swapnil Sahar, 16).

Generally flirting and trying to enjoy a close proximity with the opposite sex in our part of the world, at least, is deemed to be man'sprivilege but the case is different in this novel. Aonly daughter of a police officer father and a housewife mother, Anita did enjoy some good deal of travelling in her younger days as her father would be posted to different locations and she accompanied him with her mother. And that must have helped her become more selfconfident and an eloquent speaker as she enjoyed more exposure than Ananta.

On encountering Anita in Biratnagar after a long gap, Ananta recalls his past days at school, with her as one of his "arch" rivals who eventually and almost imperceptibly enters his life. Down the memory lane, Ananta reminisces all those yester years when he and Anita shared some sweet bitter memories for during their early school years "Anita beat him with a stick" (Swapnil Sahar, p. 15) and at the time of parting from school Ananta asked her with sadness, "Will you write to me?" (Swapnil Sahar, p. 18). But with her father's transfer, Anita too had to leave the village and that meant parting with Ananta and his family. She had already established very friendly relations with Ananta's mother and perhaps this shows of her far sightedness as despite her age she could have in her heart already chosen Ananta as her prince charming. She was probably aware that it was Ananta's mother's heart that she had to ultimately win to realize her dream of connecting with Ananta. This shows tactfulness and maturity of the female sex. However, Ananta and Anita happily renew their relationship once they reunite in Biratnagar with the same level of intimacy.

The relationship between Anita and Ananta does restart at a platonic level for "even if there was love between them, it was unexpressed, humble and friendly. He experienced her "affection everywhere" (Swapnil Sahar, p. 17) but does not stall at the same, and youthful lust does interfere for "Anita kissed on Ananta's cheek with her hot lips" (Swapnil Sahar,p. 21). However, the writer is careful not to elaborate much on the details and vulgarize it and imparts an impression on the readers that it is very natural for young lovers to enjoy some physical intimacy without defying "the limit".

Interestingly, however, it is Anita who takes the initiative in instigating physical proximity and the male character seems rather hesitant about it and was little shocked for " it was as if Ananta had experienced some kind of electric shock and he loosened his hands in discomfort" (Swapnil Sahar, p. 21). The novelist has been very careful with the use of language and does not use explicit content with a view to entertaining cheap popularity but handles such a sensitive issue of teenage love with caution. The writer, perhaps, wants to show that on the one hand women can take the initiative, but on the other hand they also present themselves in a more mature fashion.

The writer besides presenting women characters in an open-minded and change embracing light, also tries to show that indirectly, as compared to men, women are more fatalistic. This may not have been a deliberate attempt but unknowingly the novelist uses Ananta's mother's utterances such as "Whose future is secure after all!'(Swapnil Sahar 47) to introduce fatalism in the novel. Thus, no matter how understanding and open to change a woman could be, she still has the ingredients of fatalism internalized and that she simply cannot forget altogether as Anita's mother says to Ananta that "he passed SLC because of the pious deeds of his mother in the past life"(Swapnil Sahar, p. 19). The narrator also shows that women, whether as a mother, sister or a wife, always occupy a center stage on a man's life. For example, in times of difficulties for Ananta it was "mother's compassion, Anita's love and Surendra's affection that saved him from deviating...." (Swapnil Sahar, p. 38). The list could have begun with a male character such as Surendra, but it starts with Mother's mention and this clearly shows the due prominence enjoyed by women in the novel. It appears to be a deliberate attempt of the writer to establish the pertinence of women in the novel. 
In addition, the writer also shows that when it comes to mannerisms and etiquette, women have them inherently internalized. It was during her very first encounter with Prachanda, for example, that Rajani greets Prachanda by doing Namaste. (Swapnil Sahar, p. 39). Similarly, another indication that even women, regardless of their sexes, could have interest in otherwise thought to be male disciplines, is proved by Rajani for she too "prefers to study Economics but it also depended on brother." (Swapnil Sahar, p. 41). The novelist thus rejects the notion that women are more concerned with subjects that basically revolve around domesticity and tacitly they too share the drive to instigate economic development no less than men. But that "let's see what Dai says" (Swapnil Sahar, p. 41) suggests that women still depend on men's approval to some extent before embarking on any mission.

Another instance of women strength presented in the novel is their natural propensity to understand, compromise and sacrifice. For instance, when Rajani converses with Prachanda at the jail "found his words natural" (Swapnil Sahar, p. 42). She also understands that once Ananta, her brother, starts working he will not have enough time to go and see him at the jail, therefore, on his request she agrees to go to jail with him so that later she would be able to maintain regular correspondence with Ananta, and understanding the gravity of the situation she complies. Her instant approval to Ananta's proposition might be an indication that her heart had already begun beat for Prachanda.

Another instance that shows that women can compromise and sacrifice is when Rajani agrees to marry Prachanda or when that she begins to love him though there is no direct mention and elaboration of it. Prachanda was a radical political figure challenging the interest of the then functioning system and would be jailed on an off. Despite this predictably perilous reality of Prachanda, she consents to tie a knot with him. Similarly, Ananta's mother also seems to have a high degree of awareness regarding the prevalent socio-cultural practices and (most probably) unlike the women of her times-in fact even unlike most the women of the Present times-she is considerably understanding and compromising. She looks even more revolutionary in this regard for in matters in which even her educated sons remained confused she had no doubt for she stated" Ananta seems to like Anita and I should not even think of hurting someone like Anita who loves me so much" (Swapnil Sahar, p. 45). She was not opposed to inter-caste marriage and openly wanted to accept Anita as her daughter in law. To her all that counted was Anita's character and mannerism and once she realized that Anita would be a suitable candidate for Ananta she offered no resistance. In fact, she was the one the one to propose their marriage and acted as a catalyst to translate the notion of marriage into action.

Similarly, it was Ananta's mother's idea that Rajani be married to Prachanda. A typical village woman of the Panchayat era would probably never think of practicing inter-cast marriage in her family but Ananta's mother was markedly different. Here, it was upon the insistence of Ananta's mother that the marriage between Ananta and Anita had taken shape. In yet another context, it was again Prachanda's mother who wanted a nuptial knot tied between Rajani and Prachanda despite being aware thatPrachanda's life was enveloped with uncertainty. She courageously utters that "even those involved in politics have set up their families and that it was all a matter of time; once obligations start pressing everything will fall in the right place" (Nepal, p. 46).

Thus, Ananta's mother is a daring lady who openly challenged the invisible yet profound socio-cultural intricacies of her times and exhibited utmost flexibility and courage, and compromised-if at all she faked her own self- for the happiness of her children. But it went beyond that. What she did was go against the societal current and prove that despite the imposition of educational, cultural and social constraints, women are endowed with that extra ounce of confidence that levels them with men, or perhaps, even surpasses them. Another example of perseverance and understanding nature of women can be seen in Sher Bahadur's sister in law. His nephew mentions that his mother unwaveringly maintained that he (Sher Bahadur) could have never killed his brother (her husband). And for fifteen years, she barred her son from sharing their plight with his uncle, Sher Bahadur, as"he was already troubled enough and that they should not add sorrow to his already distressed life.... (Nepal, p. 48).

However, reading against the grain, it can also be inferred that not all women can be put in the same basket and that there are female characters like Sher Bahadur's wife who abandoned their loved ones in their times of difficulties and "eloped with another man deserting her husband and orphaning her two year olddaughter" (Nepal, p.48). This points towards the trustworthiness of women. Thus women of diverse nature are portrayed in the novel but most of the major female characters have valiantly stood the ordeals of life and emerged victorious in most for they always maintained a high degree of ideals and remained committed to their spirits. 
Women are also shown to be more systematic when it comes to handling family issues. A case in a point is that in the absence of Ananta, his mother is considerate enough to send Anita to her (Anita's) mother's. Likewise, even Anita is presented as someone who knows how to win over the hearts of the family members for she had been able to "quickly impress her sister in law" (Swapnil Sahar, 59). Similarly, it is with the presence of Rajani that Prachanda's house becomes livelier. However, it can also be seen that despite the courage to go against the unjustifiable currents of society, women still retain traces of hesitation when having to act against the norm of the society they belong to. Ananta's mother, for example, says to Anita that "she should return to the house at regular intervals as otherwise the gossipers might take it as my not tolerating you in the house." (58). This is more a cultural issue that have long privileged males over females in the Nepalese society. It would be pertinent here to link it to Suresh Lohani's (2019) Scholar's Social Studies and Creative Arts in which he talks about how people practice a lifestyle that is so much shaped by the cultural sites that they belong to. This may happen in both visible and invisible level (p.39). This very well reflects in the way Anant's mother counsels Anita.Therefore, despite establishing prominence of women in the novel, the writer- unknowingly or deliberately- shows that it may be impossible for women to become totally indifferent towards unjust societal pre-conceptions, especially on issues connected to domesticity.

In addition to being sensitive to societal expectations, it can also be argued that in the novel, women often seek solace and support from males in their hours of distress. For example, as she begins to sense some trouble in her married life, Rajani calls for her brother to resolve the issue. Although quite well educated herself and someone with no difficulty in being able to converse with her husband, Rajani is still not able to sort out the misunderstandings with her husband and seeks the support of her brother, Ananta. Rajani finds that a gap has begun to widen between them and to bridge this vacuum in their life she resorts to her brother. So indirectly the writer is probably trying to hint that women are still reliant on men when it comes to combating problems of their life and for that reason, are still not as liberated as they deserve to be. Similarly, even when it comes to issues of morality, it would be a hasty generalization to say that men are more corrupt than women as in the novel, together with men, even a lady minister is suspected of being involved in corruption as Binod asks Prachanda "to watch Balabhadra...and Devi and observe the changes that have come both in their perception and lifestyle" (Swapnil Sahar, p. 82). Thus, besides largely centered on the praise of women, the novelist is also trying to indicate that in place of segregating men and women in terms of virtue and vice, it is pertinent to objectively study them as human beings in the first place. Both men and women have their own strengths and weaknesses and they should not be indiscriminately analyzed.

Despite the flaws and strengths, the writer attributes to both male and female characters, the rhetorical analysis of the texts shows that the women's weight in the novel is still much lighter than that of men. This may have been the result of Hindu cultural practices that, however imperceptibly, places women beneath men. Nepal may have been unaware of how the embeddedness of that very percept in his psyche came into play when developing his characters. Suresh Lohani (2016) in "" LGBTI in NEPAL, Pakistan, and India: Law, Religion, and Individuals "posits that "in the nutshell, the law of any country and religion of any community can never be the identical reflection of the individuals who are positioned under these spaces" (p.65). However, in contrary to this argument, in some imperceptible way, Nepal has positioned his female characters in a weaker position than the male characters. To challenge this kind of portrayal of women as weak, as Ashok Bhusal (2017), in "Emphasizing the suppression of feminist voices," says, we need to include female characters "who have been largely marginalized or ignored and reclaim their contributions in the twenty-first century" (p. 56). Critical race theory along with feminism might provide a good framework for challenging the existing patriarchy inherent in our society. Bhusal (2019) explains, in his another article titled "The rhetoric of racism and anti-miscegenation laws in the United States," that "What is necessary at this point is, with the tools offered in critical race theory, is to complete a deeper study of minorities and bring their stories, their voices, into academic scholarship" (p. 88). In another article titled "The rhetoric of racism in society," Bhusal (2019) says that racism has caused an identity crisis for minorities as they "question their own identitity and put down their own traditions to acquiesce to the majority" (p. 114)

The novel has male characters in the lead and the women seem to be moving on the margin as sidekicks. Whether it is Ananta's mother or sisters or whether it is Anita and her mother, they do not seem to impact much on the novel though comparatively Anita and Rajani enjoy a better status. Apart from Anita and Ananta's mother, other lady characters do not seem to carry any load of the plot and they just follow as blur shadows alongside the male characters such as Ananta. And even Anita's role is largely downsized upon Ananta's departure to Kathmandu from Biratnagar. Although Ananta's motheris projected as a powerful lady who has her way in all matters connected to her family and exhibits enough influence on people around her, the space she is allotted in the novel seems little too 
congested. And yet there are other remote female characters such as Sher Bahadur's wife, who simply fail to make their presence felt in the novel. But it would be quite unfair to state that women do not have a meaningful existence in the novel and that in the absence of women characters the male characters appear incomplete. Despite the limited coverage ascribed to women, the attributes they uphold do seem meaningfully significant. It would thus be no fabrication to state that the female characters in Nepal's novel have conditioned the plot largely, yet it is under the shadow of male characters that they are positioned.

In the context of teaching students regarding how to write this kind of novel, as stated by by Ashok Bhusal (2010), teachers should ask their "students to find out the reasons of their writing, the subject they are talking about, and the participants in these interactions to make them aware of the genre expectations" (p. 13). Although there are some scholars who believe "genre stifles students' creativity since it makes them aware of constraints" (p. 15), a prominent genre scholar, Ashok Bhusal, makes it clear that genre increases students' creativity by making students conscious of rules and also offering flexibility to be creative.

\section{References:-}

1. Bhusal, A. (2017). Emphasizing the suppression of feminist voices. International Journal of Humanities and Cultural Studies, 4(2.

2. Bhusal, A. (2017). The rhetoric of racism and anti-miscegenation Laws in the United States. IAFOR Journal of Arts and Humanities, 4(2).https://doi.org/10.22492/ijah.4.2.07

3. Bhusal, A. (2010). Genre awareness in the writing center. MA Thesis, Department of English, Eastern Illinois University, Illinois.

4. Bhusal, A. (2019). The rhetoric of racism in society. Journal of Research Innovation. 9(1).

5. Lohani, S. 2016. LGBTI in NEPAL, Pakistan, and India: Law, religion, and individuals. MPhil Thesis, Department of English, Pokhara University, Nepal.

6. Lohani, S. (2019). Constructing nontraditional rhetoric: Critical study on Gloria Anzaldua and Suresh Canagarajah. Journal of Research Innovation. 9(1).

7. Lohani et al. (2015). Scholars' social studies and creative arts series for primary level students, approved by Curriculum Development Centre Nepal, Kathmandu: Scholars Publications and Printing Pvt.Ltd.

8. Jacobs, R. (2001). A beginner's guide to critical reading an anthology of literary texts, Routledge, London and New York.

9. Nepal, P. (2062 B. S.). Swapnil Sahar. 